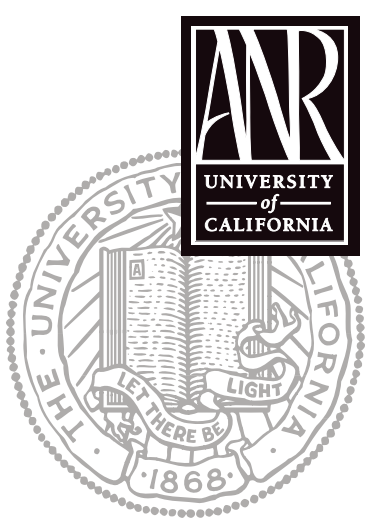

UNIVERSITY OF CALIFORNIA

Division of Agriculture and Natural Resources

http://anrcatalog.ucdavis.edu

Perhaps no other structural component of the environment is as important to salmon habitat as is large woody debris.

-National Research Council, U.S. National Academy of Sciences, in Upstream: Salmon and Society in the Pacific Northwest, 1996.

\title{
Maintaining Wood in Streams: A Vital Action for Fish Conservation
}

JEFF OPPERMAN, Postdoctoral Researcher, Center for Watershed Sciences, UC Davis; ADINA MERENLENDER, Cooperative Extension Natural Resource Specialist, UC Berkeley; and DAVID LEWIS, UCCE Watershed Management Advisor, Sonoma County

Large woody debris (LWD) is a critically important resource for California's fish and wildlife. "Large woody debris" is defined as trees, logs, rootwads, and large tree branches that fall into streams and interact with the water, sediment, and organisms in the channel (Figure 1).

Recent research has confirmed that LWD plays a vital role in many stream ecosystems, helping to control the very shape of the channel and providing cover, shelter, and feeding opportunities for aquatic organisms. Unfortunately, California's streams have lost much of their large wood as a result of human actions. At the same time, the forests and woodlands that should have provided a continuing natural source of LWD in the future have been altered. Now that the role of wood in streams is better understood, land managers and resource agencies have begun both to restore LWD itself and to improve LWD recruitment on timberland. The importance of instream wood is not restricted to timberland, though: LWD is an important natural resource across a diverse range of California's streams. This publication is intended to provide LWD information for non-timber landowners including ranchers, farmers, and rural and suburban residents.

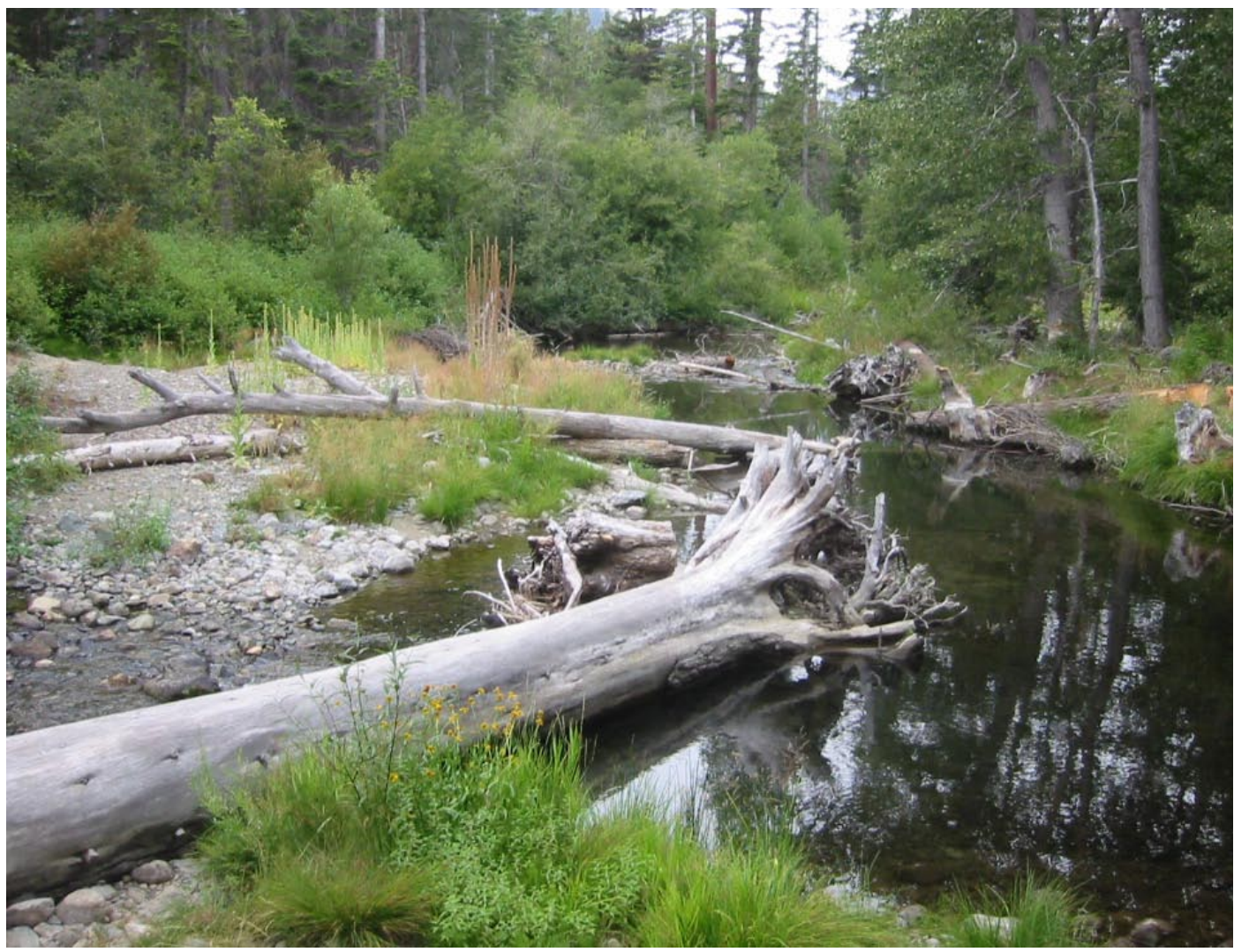

Figure 1. Large woody debris (LWD) creates important habitat for fish and other aquatic species. 


\section{THE BASICS OF LWD}

\section{Large Wood, Stream Channels, and Aquatic Ecosystems}

In many watersheds, large woody debris is a primary factor controlling the shape of the stream channel. When a large piece of wood enters and stays in a stream, it can interact in numerous ways with flows of water, sediment, and nutrients. For example, a log can concentrate high water flows down into the stream bed, scouring out a pool (Figure 2). Research has shown that for many streams, the more wood that is present, the greater the number of pools. These pools are very important to fish and other aquatic organisms, and the wood within these pools provides cover and shelter.

Water and sediment can become partially dammed above a large log or group of logs. This can create an area of calm water in an otherwise steep, fast-running stream. Gravels that are the right size for salmon spawning can also be deposited in these
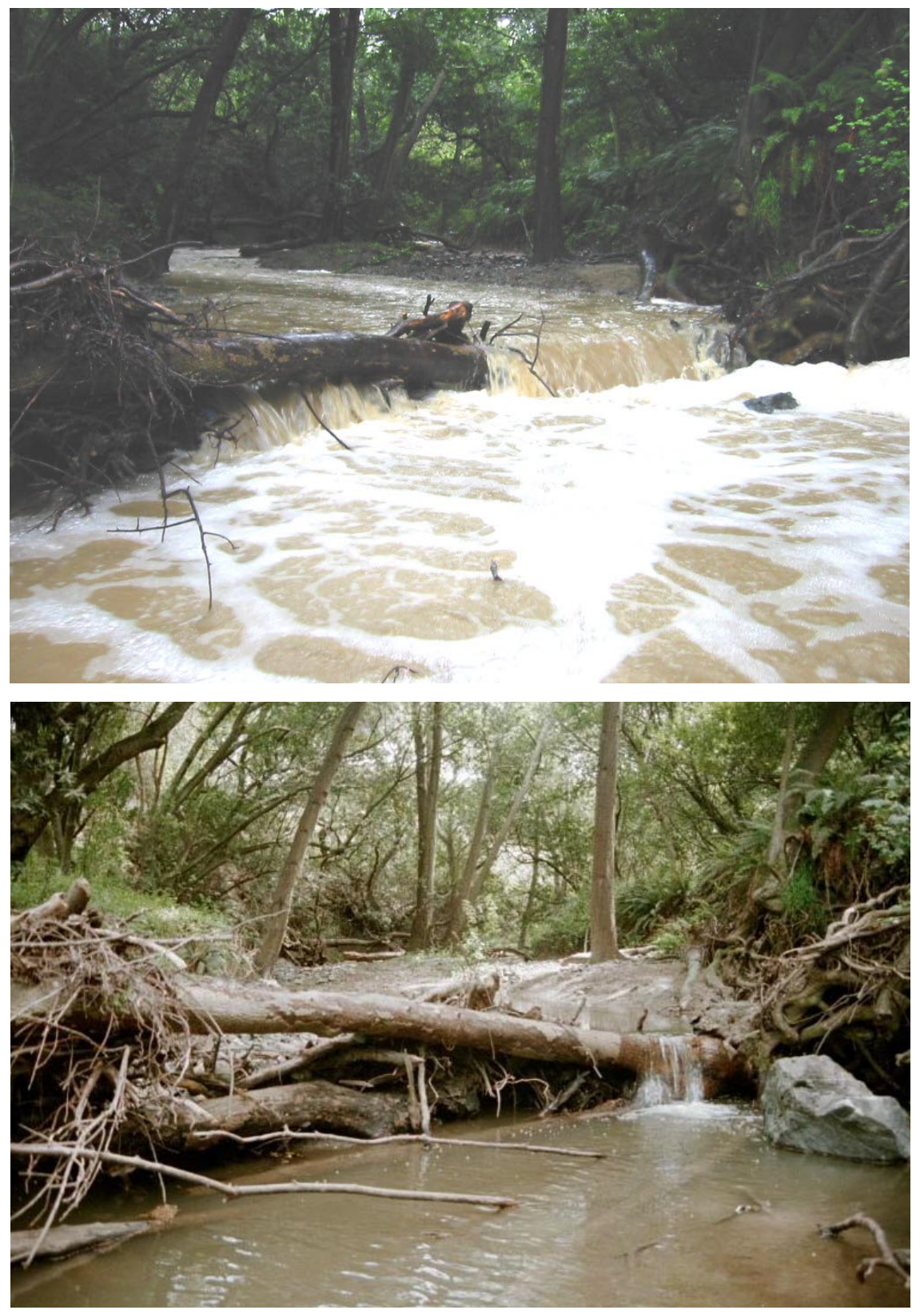

Figure 2. This log stores sediment upstream and during high flows it scours out a pool. The top photograph was taken during a winter storm while the one above was taken during summer baseflow. relatively calm areas. In fact, in some steeper streams most of the suitable spawning sites are located upstream of large woody debris. Additionally, dense regeneration of riparian trees can occur in the fine sediments deposited above an accumulation of large wood.

Large woody debris also plays an important role in aquatic food webs. This role ranges from trapping and storing organic matter to providing direct food sources and habitat for aquatic insects, such as mayflies, stoneflies, and caddisflies. Logs decay relatively slowly and do not have high concentrations of nutrients or biologically available energy. However, just as LWD traps sediment, it can also trap organic matter such as small logs, twigs, leaves, and even salmon carcasses that remain after spawning (Figure 3). These materials form the energetic and nutritional foundation of food webs in most small streams. In small streams that lack large wood, much of this material is flushed downstream, whereas streams with an abundance of LWD retain this material, making it available for the aquatic food web. One study found that $75 \%$ of all organic matter within a stream was stored by LWD.

Many insects and other invertebrates-both terrestrial and aquaticare specialized to inhabit and utilize wood in various states of decay. In addition, LWD provides a substrate upon which fungi and algae grow. This 


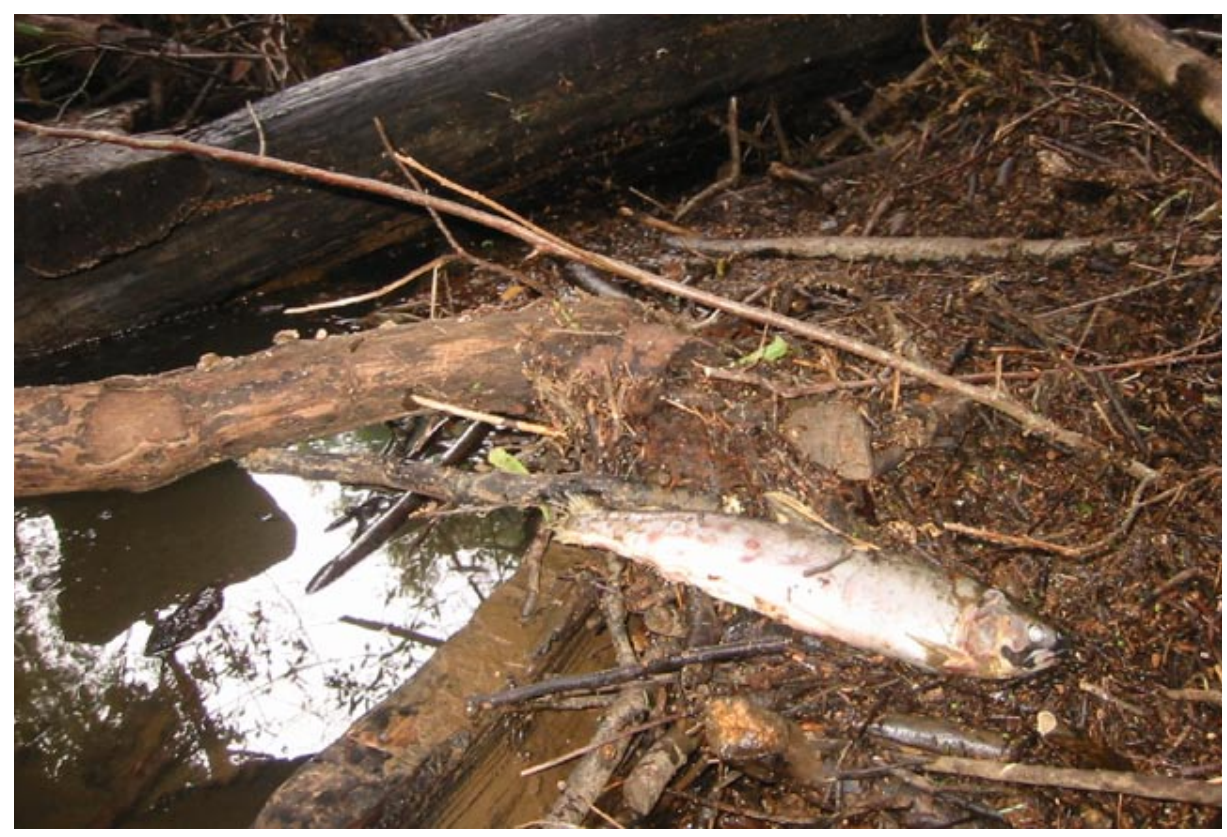

Figure 3. After salmonids spawn and die, their carcasses can be trapped by large wood. The nutrients in the carcasses can then become available to the stream food web, ultimately supporting the growth of juvenile fish.

\section{Large wood and fish habitat}

Recent research has clearly demonstrated that large woody debris is a particularly important habitat element for anadromous fish in coastal watersheds and that current low levels of LWD may be among the primary reasons for depressed populations of salmon and steelhead. In their 1996 review of the decline of salmon populations Upstream: Salmon and Society in the Pacific Northwest, the National Research Council concluded that "perhaps no other structural component of the environment is as important to salmon habitat as is large woody debris."

Large woody debris can improve habitat throughout the life history of anadromous fish (Figure 4). Large wood can prevent spawning-sized gravel from being flushed downstream during high flows. Accumulations of gravel can occur upstream of LWD; in some steep stream reaches, these wood-influenced depositions provide the only suitable locations for spawning. Wood in rivers can aid adult salmon during their upstream migration growth, which appears to coat the wood in streams with a brown film, is the primary food source for a group of aquatic insects called scrapers. In turn, these and other stream insects provide the primary source of food for fishes such as steelhead trout, coho salmon, and sculpin.

Not all streams would contain significant amounts of large wood in their natural state, including streams where the riparian corridor is dominated by shrubs or grasses and channels where a high stream power means that wood is rarely stable and persistent. In these streams, habitat can be provided by other features such as boulders and undercut stream banks. Because of the natural variability of wood in streams, it is important to understand the historic range of variability of LWD in a given region and channel type before you assume that a stream is deficient in wood.

\section{How Wood Enters and Leaves a Stream}

Wood enters (is recruited to) streams through a variety of mechanisms including bank erosion, landslides, windthrow, and the falling of dead trees and limbs. Landslides may be the dominant factor in steep watersheds while bank erosion may dominate in alluvial valley channels. In ecosystems where fire is common as it is in the intermountain West, most wood may be recruited in the years following a major fire. The diversity and variability of recruitment processes and stream types make it very difficult to say how much LWD "should" be in a channel at any one time. The amount of wood changes over a period of years and decades and varies from stream to stream, even within the same watershed. For example, a survey of Wildcat Creek, a lightly managed stream in a regional park near Oakland, California, found 25 debris jams (accumulations of wood) in 1987. In 2001 that same stretch of stream contained well over 100 debris jams. 


\section{Large wood and fish habitat}

(continued from $p$. 3)

by providing areas of low water velocity in which to rest. When the fry emerge from the gravels, wood in the stream can add variety to the habitats available, including low-velocity areas where juveniles can seek refuge. Through a variety of mechanisms, LWD can greatly boost aquatic food webs, providing juvenile fish with the energy needed for growth.

Juvenile coho salmon need to survive one summer and one winter in a stream before they migrate to the ocean, and steelhead require at least two summers and winters, sometimes three, before they migrate to the sea. Pools are particularly important as rearing habitat for juvenile coho and, in areas with a pronounced summer dry season, deep pools may provide the only available habitat for any fish as the streams begin to dry.

There must be sufficient cover in these pools if fish are to survive (Figure 5). Without cover, the fish are very vulnerable to predators such as herons and raccoons. Large wood can improve a fish's chances for over-summer survival in two ways: by forming pools within a reach and by providing cover for those pools. During winter, juvenile salmonids are vulnerable to high flows. Without cover, young fish can expend too much energy trying to fight the current or they can be washed downstream. Accumulations of wood provide excellent refuge locations where fish can avoid the fast currents. For these reasons, fish have much higher over-winter survival rates in reaches that have greater levels of LWD.

The presence of LWD improves habitat for salmonids throughout their lives, providing essential protection from predation during the summer and a secure place during high winter flows. Although most research has focused on the role of LWD in freshwater environments, there is also evidence that wood provides important benefits to fish and other aquatic organisms in estuaries and even in the open ocean. There is no doubt that wood is an essential habitat element for salmon and steelhead.
Figure 4. Large woody debris provides important habitat benefits throughout the life history of salmon and steelhead. As adults return from the ocean and migrate up rivers and streams to spawn, LWD can provide cover and low-velocity areas for resting. Large wood can also cause deposition of spawning size gravels. After emergence, LWD provides juvenile fish with shelter during high flows, pools for rearing during low flows, cover from predators, and, in various ways, large wood promotes the aquatic food webs that provide food to growing fish. Wood continues to provide cover during estuary rearing.
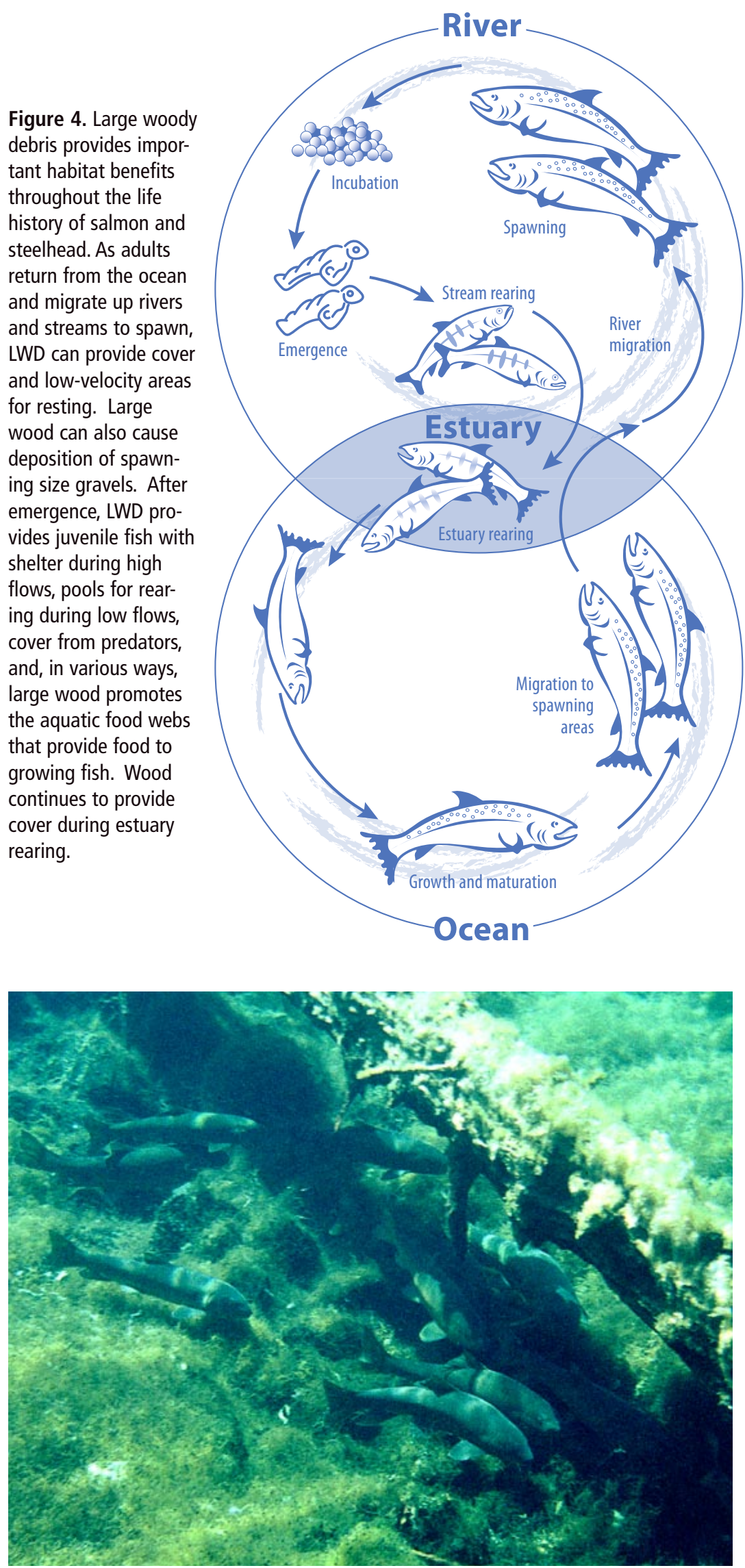

Figure 5. LWD can protect fish from predators. Photo by Thomas L. Taylor, @2006 


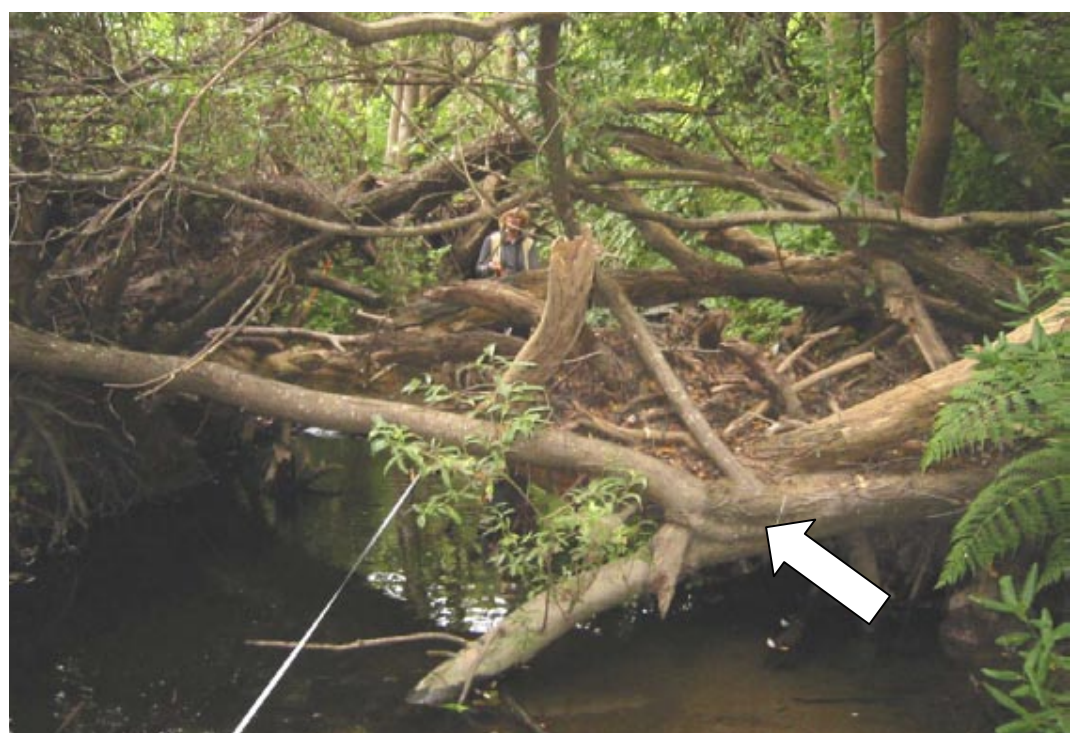

Figure 6. A debris jam has formed behind this key piece of debris (white arrow). Note that there are green sprouts to the left of the arrow indicating that this key piece is still alive. This debris jam illustrates two key functions of LWD: pool formation and cover.
Once LWD enters a stream, the processes of transport and decay gradually remove it from the channel. During high flows, wood can be transported downstream or deposited on the stream's floodplain. The ability of a piece of wood to resist this kind of transport and to remain in place is determined by the size of the piece relative to the size of the channel. In very small streams, most pieces of wood are stable because they extend across the channel and are in many cases anchored by standing trees. In large streams and rivers, most LWD is mobile and wood is generally confined to channel banks where it is deposited as high flows recede.

The transport of wood is also influenced by the presence of key pieces in a channel. Key pieces are the pieces of wood that remain stable in the channel and strongly influence the transport and deposition of LWD (Figure 6). Because they are stable and interact with high flows, key pieces trap much of the wood that is in transport in the water. Wood that would otherwise be flushed downstream becomes trapped and stored behind these key pieces. Streams that lack key pieces will tend to have a much higher rate of wood transport and a smaller amount of persistent LWD.

The wood's rate of decay is strongly controlled by attributes of the piece of wood itself, including its diameter, its density, and the presence or absence of decay-resistant chemicals in the wood. Because decay generally progresses from the outside inward, the greater the diameter of the piece, the slower its decay will be, due to its ratio of surface area to volume. A larger piece of wood also has a greater proportion of dense heartwood in its center and this makes it more resistant to decay. The wood from conifer trees such as redwood and Douglas-fir generally decays more slowly than the wood from hardwood trees such as alders are willows. The same properties that makes redwood highly desirable when you are building a deck also make it more persistent as LWD in streams.

\section{LARGE WOODY DEBRIS AND LIVING KEY PIECES IN HARDWOOD-DOMINATED WATERSHEDS}

The majority of research conducted on LWD has taken place in watersheds dominated by large conifers such as redwood and Douglas-fir. In these watersheds, wood provided by riparian hardwoods_-such as alder, willow, maple, and ash-is generally considered to be insignificant or inferior. This is because of the wood's smaller size and generally faster rate of decay. The term hardwood does not actually refer to how hard the wood is; rather, it is a generic term that distinguishes broadleaf trees from conifers (see Glossary).

In California, many watersheds, including many that support anadromous fish, have few or no conifers (Figure 7). As an example, most of the fish-bearing tributaries of the Russian River (north of San Francisco in Sonoma and Mendocino Counties) are dominated by hardwoods. The hardwood watersheds tend to be those with a Mediterranean climate: cool, wet winters and hot, dry summers. Does LWD play an 


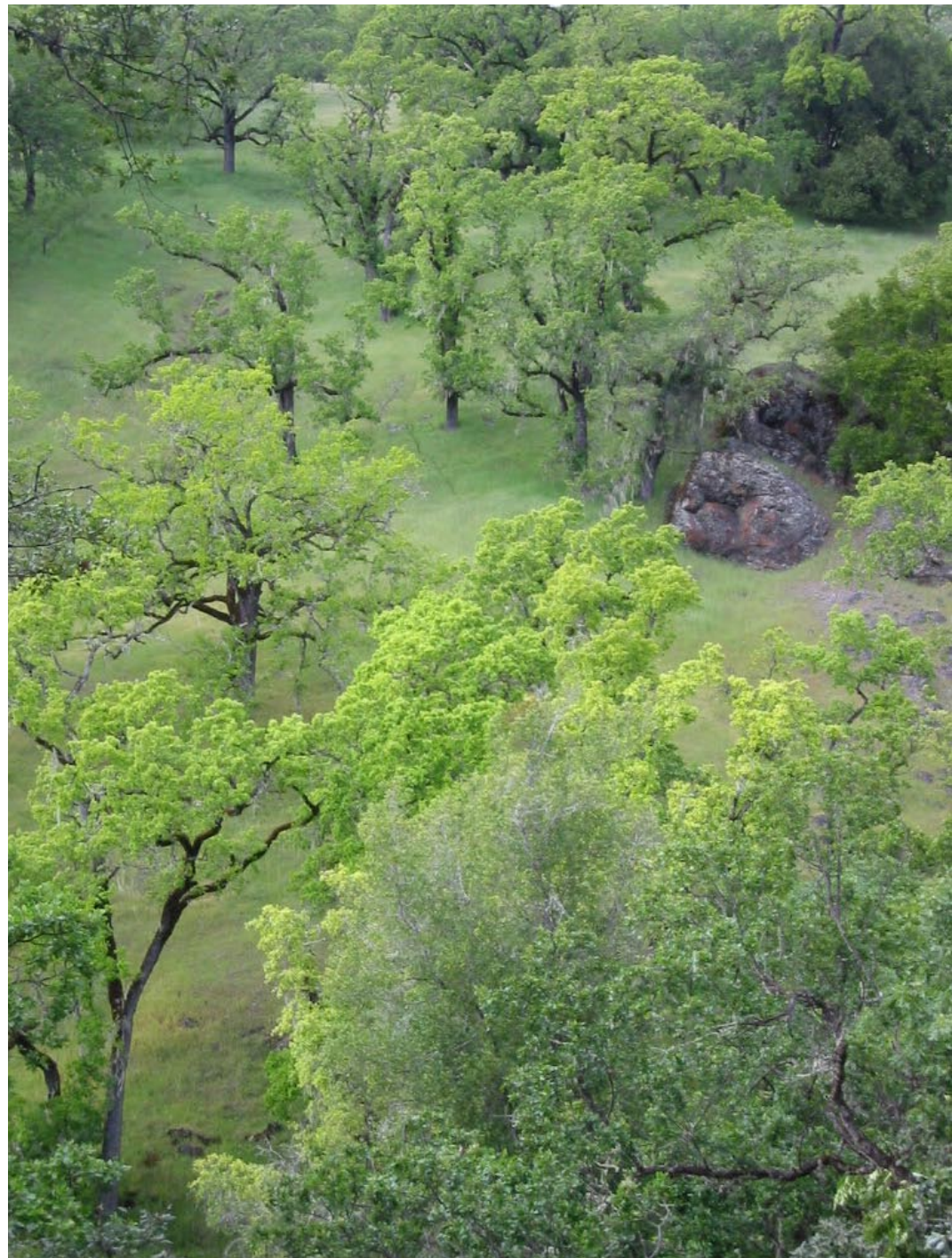

Figure 7. Many of California's hardwood-dominated watersheds support runs of salmon or steelhead.

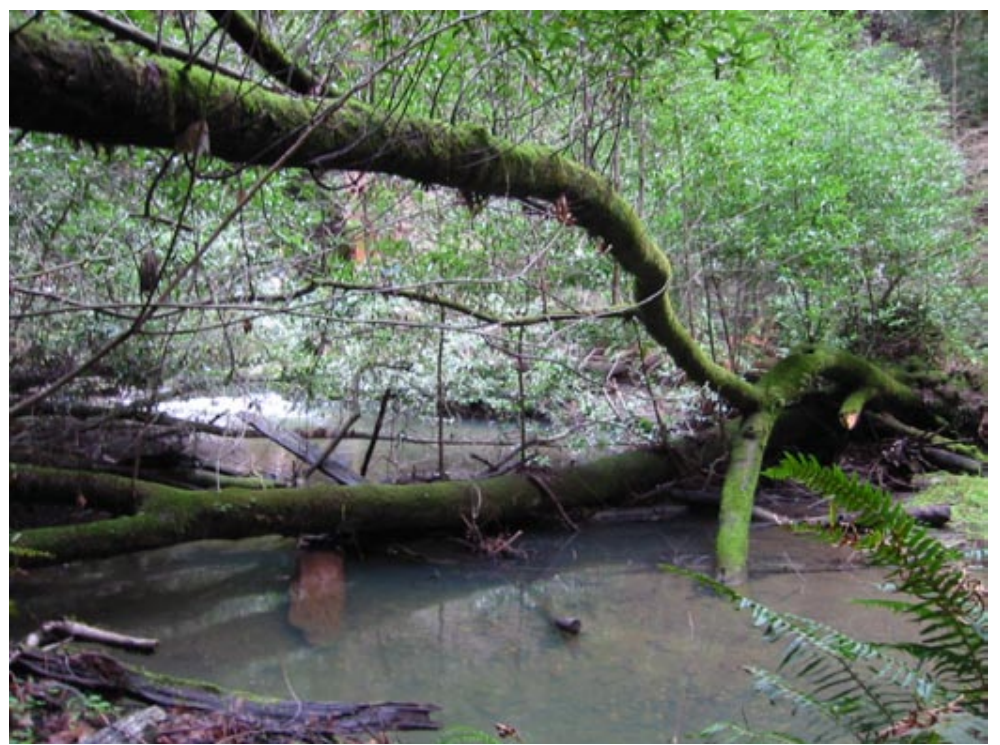

Figure 8. A California bay laurel has fallen into this stream, but remains rooted and living. Numerous sprouts can be seen along the main branches, and the tree is now spanning the stream and contributing to the formation of a pool and storage of organic matter. important role in these streams? Fish living within these watersheds must survive under the low-flow conditions of the dry, hot summers and could certainly benefit from the pool formation and cover that large wood provides. Recent research has found that, indeed, LWD from riparian hardwoods does provide many of the same habitat benefits-pool formation, cover, and shelter-that have been reported from conifer watersheds.

How does LWD from hardwoods provide these benefits if it is generally smaller and quicker to decay? One mechanism that appears to be important is LWD that is still living (Figure 8). Although LWD has generally been considered synonymous with "dead wood," some tree species can function as LWD while they are still alive. Many riparian hardwoods, including willows, alder, and California bay, have very flexible growth patterns. These trees can often continue living and growing after they fall into the stream, so long as their roots remain in contact with the bank. Often the top of the tree will re-orient and grow vertically, or some of the major branches will become the dominant canopy. These down trees function both as LWD-because they are horizontal and interacting with the channel-and as part of the riparian forest. Because they are still alive they won't decay and because they are still rooted to the bank they will tend to be much more stable during high flows. Living LWD appears to be one way that riparian hardwoods compensate for their smaller size and faster rate of decay.

\section{HUMAN ACTIVITIES AND LWD}

Human activities have greatly influenced the amount of wood in California's streams and the processes by which LWD enters and leaves streams. Numerous research studies have concluded that streams contain far less large wood now than they did before European settlers began managing the landscape.

As Europeans settled in the West they encountered big rivers that were full of large trees and accumulations of LWD. To improve navigation on these rivers, settlers 
removed large logs and debris jams within the streams. In some locations they also cut riparian forests to fuel the engines of steamboats. Although these efforts improved river navigation, they also resulted in significant changes to the diversity of habitats within large river corridors. Timber harvest also began to influence the levels of LWD in streams and altered the processes by which new wood was recruited. In some reaches, nearly all LWD was removed because streams were used as roads or channels to transport wood below "splash dams." A splash dam was a temporary dam built to store a large quantity of wood in an upstream reservoir. Eventually the dam would be dynamited, sending a huge wave of water and wood downstream. This wave also removed all of the instream wood and many of the riparian trees along the channel below the dam. Channels below a splash dam could be scoured down to the underlying bedrock. Timber harvest also influenced LWD dynamics by removing the large riparian trees that could have served as LWD and key pieces in the future.

At times, timber harvest resulted in the deposition of logging debris-called slash-in creeks. In some places, these accumulations of wood were so thick that they became migration barriers blocking fish as they attempted to travel upstream. To remedy this legacy of logging, resource agencies across the West then engaged in woodremoval programs. These "stream-cleaning" operations often removed much of the naturally occurring wood and debris jams along with the logging slash. Until recently, resource agencies assumed that many debris jams were barriers and removed them under goals of salmon habitat restoration. Scientists who have studied fish movement and debris jams have now found that naturally occurring debris jams are very rarely barriers to fish (see sidebar: Debris jams and fish passage). Nowadays, restoration programs are adding wood back to streams, either by placing log structures (Figure 9) or by encouraging riparian restoration that will provide for long-term LWD recruitment.

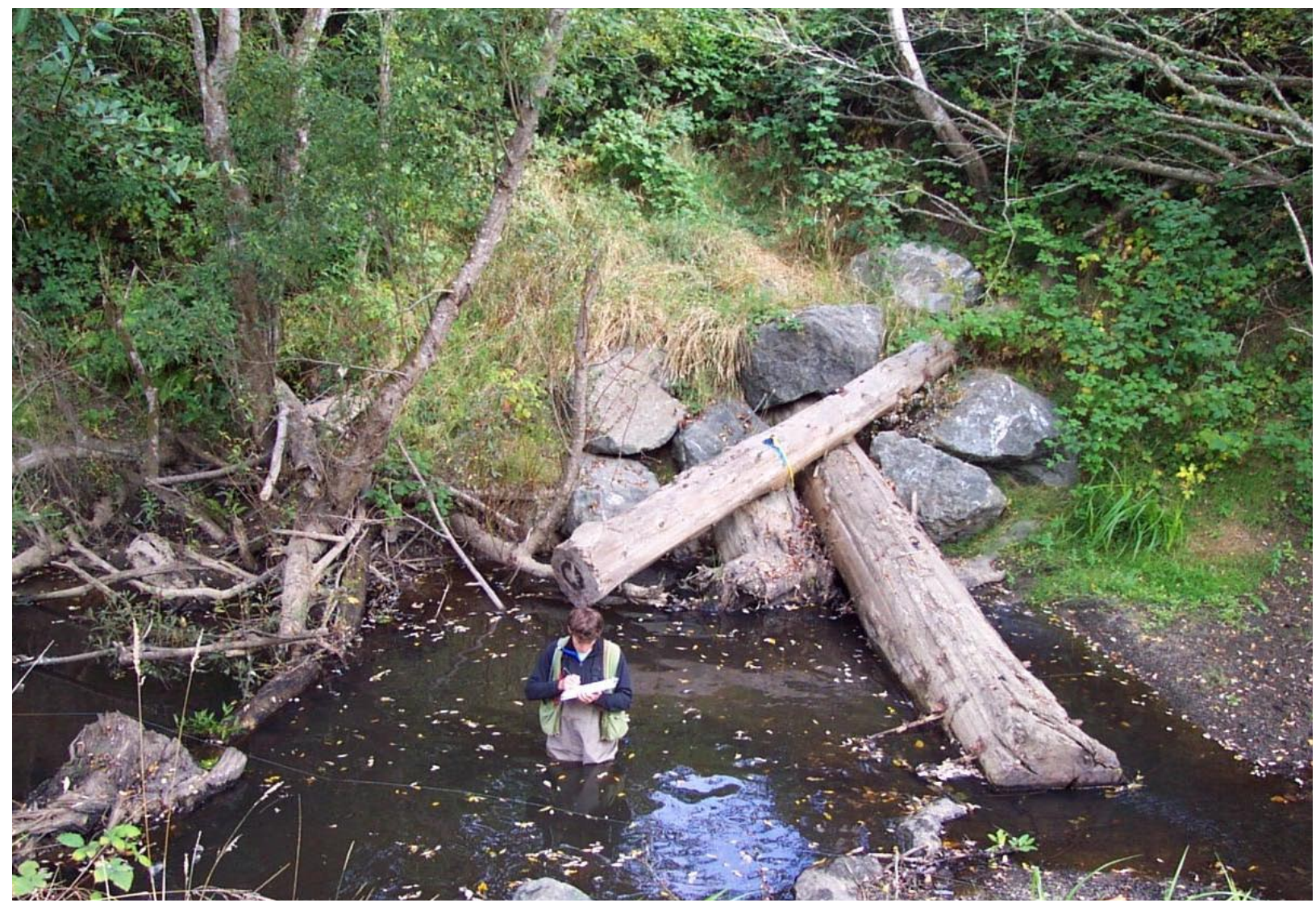

Figure 9. Numerous agencies, organizations, companies, and landowners are now adding large woody debris back into streams as shown here (two logs anchored with boulders). Photo by Karen Bromley. 


\section{Debris jams and fish passage}

People often think that large logs or woody debris jams that span a stream will create a barrier to fish passage. This misperception is the result of several factors, including

1. The legacy of "stream cleaning." Excessive amounts of logging slash deposited in a single place in a stream can create a barrier. This practice is not permitted under the California Forest Practice Rules, but high levels of slash in channels have historically provided the impetus for "stream cleaning" programs by government resource agencies. These stream cleaning programs often also removed naturally occurring debris jams. The overall effect was not only to reduce levels of LWD in western streams; it also left as a legacy the misperception that debris jams block fish movement.

2. Apparent condition depending on time of year. Debris jams are generally observed during summer low flows. They are rarely observed during winter high flows, when most adult migration to spawning streams occurs. During high flows, debris jams can become submerged as water goes over the top of them or they can float or "raft" upward as water flows underneath. Fish are very adept at finding spaces above, below, around, or within a debris jam where passage is possible. In fact, accumulations of wood can provide low-velocity areas where migrating adults can rest before they resume their swim upstream. If you think that a LWD deposit is a potential barrier to fish, try to envision how water will flow over, under, or around it during high flows (e.g., see Figure 2). A fisheries biologist from the California Department of Fish and Game can tell you whether the wood is indeed a fish barrier. In the rare cases where a jam does form an impassible barrier, sometimes you only need to remove a few pieces of wood to allow fish passage, while still leaving enough material in place to provide the habitat benefits of large wood.

\section{BALANCING THE BENEFITS OF LWD WITH ITS POTENTIAL RISKS}

The management of timberland riparian areas is now regulated under the California Forest Practice Rules adopted in 1974. The Forest Practice Rules require that riparian buffers be managed to provide shade and protect stream banks. These riparian areas also allow large trees to develop and, over time, fall into the streams. Many timberland owners are also now adding wood to streams through restoration projects. To achieve widespread habitat improvement for salmonids and other aquatic species, we need to see this same commitment to the retention of as much natural instream wood as possible among landowners across California, including ranchers, farmers, rural and suburban residents, and local agencies (e.g., flood-control districts).

Currently, landowners and agencies remove wood from streams for several reasons. In some places, accumulations of wood can threaten bridges or culverts and LWD accumulations have the potential to promote bank erosion or localized flooding near a road, house, or other structure. For these reasons, we need to manage wood in streams in a way that balances the ecological benefits of instream wood with public safety. A lot of wood is removed from streams in error, however, because of misperceptions of the role of LWD role in streams. Many people still see wood as a potential barrier to fish migration, so they pull wood out to "help the fish." Others may cut instream LWD to use as firewood without realizing the particularly valuable role that the wood plays in the stream. Many landowners have a tradition of maintaining a "clean" stream and have simply always removed wood as part of their regular management activities. Others perceive that wood in a stream is unsightly and so remove it for aesthetic reasons. Many landowners just don't realize that wood in streams can actually help prevent erosion by armoring banks and preventing the down-cutting that would otherwise lead to bank erosion.

Although there is some potential for LWD to damage roads or structures, one of the most common reasons people remove wood from streams is because they do not know or fully understand its role in stream ecology. Learning about the role of LWD and seeing it from a fish's perspective can greatly change the way we view logs in streams. Over time, these new perceptions should result in more wood being left in streams, balanced with reasonable measures to maintain safety and reduce risks. The sidebars How to promote LWD in streams and Guidelines for managing instream LWD provide some pointers about how to manage wood in your stream. 


\section{How to promote LWD in streams}

1. Do not disturb naturally occurring wood that is already within a stream channel unless doing so is necessary to ensure safety and protection of investments. If you are concerned about wood in your stream, please review the Guidelines for managing instream LWD in this publication.

2. When building, maintaining, or improving roads, ensure that culverts and bridges are of sufficient size to allow flood flows and LWD to pass through or under them. Besides protecting the road crossing, this will also improve downstream habitats and reduce the need to remove large wood from upstream (see the Handbook for forest and ranch roads listed under Additional Information Sources).

3. Protect riparian corridors to ensure that the stream will have a sufficient natural source of woody debris in the future. If your riparian corridor is very narrow or degraded, consider riparian restoration. Determine whether the lack of riparian vegetation is a result of livestock or deer browsing and, if so, take appropriate measures to reduce this browsing pressure (e.g., fencing or rotational grazing that reduces browsing on riparian plants during critical times of the year). Planting, protecting, and irrigating native plants can be necessary in places where natural regeneration is very slow or unlikely to occur. Also, prevent the establishment and spread of invasive species such as giant reed (Arundo donax) that can outcompete native riparian trees.

4. It is important to think about wood in streams as a process that changes over time rather than a single snapshot of LWD in the channel. Seen in this way, maintaining, protecting, and restoring riparian corridors are the best ways to ensure the long-term presence of appropriate amounts of LWD in the stream. In the short term, however, streams may benefit from restoration projects that involve putting large wood into the channel. This is particularly true for a reach with a very young riparian corridor in which natural recruitment of woody debris may be decades away. If this is your situation you can contact the California Department of Fish and Game and other organizations (such as your local Resource Conservation District or the U.S. Natural Resources Conservation Service) to learn what technical and financial assistance may be available to help you conduct LWD restoration projects on your property. It is also important to contact CDFG to determine what permits you may need to secure before you can add wood to streams and what requirements may apply for anchoring wood during a restoration project.

\section{GLOSSARY}

anadromous fish. Fish species that spawn in fresh water and mature in salt water, such as salmon and steelhead trout. Steelhead are the anadromous form of rainbow trout.

debris jam or debris accumulation. A collection of multiple pieces of LWD. A debris jam can span a channel or it can be concentrated along the bank edge. Because an accumulation is made up of multiple pieces of LWD, it can be very large and can exert a strong influence on the dynamics of the channel. Debris jams are often stabilized by a key piece.

hardwood tree species. "Hardwood" is a generic term for a broadleaf tree (i.e., a tree that is not a conifer). This includes both deciduous trees (willow, alder, cottonwood, Oregon ash, maple, sycamore, and blue, valley, and black oaks) and evergreen trees (California bay laurel, coastal live oak, and canyon live oak). "Hardwood" doesn't specifically refer to how hard the tree's wood is. Some hardwoods, such as alders, have very soft wood, whereas others such as oaks have wood that is very dense.

key piece. A piece of LWD that, either because of its size or because of its position, is stable within a stream channel. Because it resists being moved by high flows, a key piece can trap and stabilize other pieces of wood, creating a debris jam. A key piece can be thought of both as the piece that is responsible for creating a debris jam and as the piece responsible for stabilizing and maintaining the debris jam.

large woody debris (LWD). Logs, branches, rootwads, or entire trees that enter and interact with a stream channel. To be considered LWD, a piece of wood generally needs to exceed certain minimum dimensions. Common minimum dimensions in the scientific literature are at least $10 \mathrm{~cm}$ (4 in) in diameter and at least $1 \mathrm{~m}(3.3 \mathrm{ft})$ long. There is some controversy over use of the word "debris," which, some argue, may be mistaken as a synonym for the word "garbage." This has contributed to misperceptions of LWD, sometimes leading to its removal from streams. Nonetheless, large woody debris and LWD are the commonly accepted terms for wood in streams within the scientific literature and are used extensively by fisheries biologists, stream geomorphologists, foresters, resource agency staff, and land managers. In this publication we use both of these terms, along with the simpler term "large wood." 


\section{Guidelines for managing instream LWD}

1. If you are thinking about removing LWD for aesthetic reasons or as a source of firewood, consider the valuable ecological role that LWD plays in streams and the fact that the presence of wood in streams is a sign of a healthy, functioning stream ecosystem. Besides that, wood in streams is a regulated resource under the purview of agencies such as the California Department of Fish and Game (CDFG). In many cases you can save yourself work and money by simply leaving the down wood in the stream.

2. If you are considering removal because of concern for fish (e.g., fear that fish passage may be blocked), remember that fish will primarily be attempting to pass by the LWD during relatively high flows and that water-and fish - will very likely be able to pass through, over, under, or around the wood during these flows. If you are still concerned that the wood may be a barrier, consult with a fisheries biologist (at the CDFG, for instance).

3. If you are concerned that the LWD will lead to bank erosion, take a good look at what is at risk on the banks. If there are no nearby structures or roads or if the riparian corridor is wide enough on the edge of the bank to absorb some erosion, remember that bank erosion is a completely natural process. In fact, bank erosion is a primary mechanism for bringing the ecologically valuable wood into the stream.

4. If you are concerned about nearby buildings, roads, or bridges, contact your local water district or the U.S. Natural Resources Conservation Service for local contacts who may be able to help or advise you. Always notify the nearest office of the California Department of Fish and Game before you alter wood and other material in a stream, as that is the regulatory agency that oversees stream alterations. If an alteration of the material in a stream is deemed necessary, consider modifying the accumulated wood or down log in a way that will reduce the threat but still maintain some of the habitat benefits. For example, a large log spanning a channel (i.e., perpendicular to the stream's natural flow) can be moved so that it is closer to parallel with the flow. This will greatly reduce the log's effect on flood stages and its ability to trap other wood, but will still provide many of LWD's ecological benefits.

\section{ACKNOWLEDGMENTS}

Sierra Cantor and Derek Acomb, along with numerous landowners and two reviewers, have provided valuable comments on the content presented in this publication. Thanks to the administrators of the Renewable Resources Education Act for funding the development of this publication.

\section{ADDITIONAL INFORMATION SOURCES}

California Department of Fish and Game (CDFG). 1998.

California salmonid stream habitat restoration manual,

3rd edition. Sacramento: CDFG.

http://www.dfg.ca.gov/nafwb/manual.html

Fox, M. 2004. Large woody debris: How much is enough? Seattle: Center for Streamside Studies, University of Washington. http://depts.washington.edu/cwws/Outreach/FactSheets/lwd.pdf

Land and Water Australia. 2002. Managing woody debris in streams. Fact Sheet \#7. Canberra: Land and Water Australia. http://www.rivers.gov.au/acrobat/facts07.pdf

Maser, C., and J. R. Sedell. 1994. From the forest to the sea: The ecology of wood in streams, rivers, estuaries, and oceans. Delray Beach, FL: St. Lucie Press.

Weaver, W. E., and D. K. Hagans. 1994. Handbook for forest and ranch roads: A guide for planning, designing, constructing, reconstructing, maintaining and closing wildland roads. Available for $\$ 25$ through the Mendocino County Resource Conservation District Office, 405 Orchard Avenue, Ukiah, CA 95482. (707) 468-9223. http://mrcd.ca.nacdnet.org

\section{AGENCIES AND ORGANIZATIONS}

The following agencies and organizations can provide further information about managing and restoring LWD in streams.

California Department of Fish and Game, (916) 445-0411. http://www.dfg.ca.gov

Find a list of regional offices and contact information online at http://www.dfg.ca.gov/regions/regions.html

Natural Resources Conservation Service (NRCS), California Headquarters, (530) 792-5600 http://www.ca.nrcs.usda.gov

Resource Conservation Districts (RCDs), (916) 457-7904

http://www.carcd.org

Find an online map of California's RCDs at

http://www.carcd.org/wisp/rcdmapl.htm

NOAA Fisheries Southwest Regional Office, (562) 980-4000. http://swr.nmfs.noaa.gov 
University of California, Division of Agriculture and Natural Resources

http://ucanr.org

Find an online list of Cooperative Extension county offices at http://ucanr.org/ce.cfm

Find the UC Integrated Hardwood Range Management Program online at http://danr.ucop.edu/ihrmp

\section{FOR MORE INFORMATION}

You will find related information in these titles and in other publications, slide sets, CD-ROMs, and videos from UC ANR:

Fish Habitat in Freshwater Streams (Farm Water Quality Planning Series), Publication 8112 Guidelines for Managing California's Hardwood Rangelands, Publication 3368

Sediment Delivery Inventory and Monitoring: A Method for Water Quality Management in Rangeland Watersheds (Rangeland Monitoring Series), Publication 8014

To order these products, visit our online catalog at http://anrcatalog.ucdavis.edu. You can also place orders by mail, phone, or FAX, or request a printed catalog of publications, slide sets, CD-ROMs, and videos from

University of California

Agriculture and Natural Resources

Communication Services

6701 San Pablo Avenue, 2nd Floor

Oakland, California 94608-1239

Telephone: (800) 994-8849 or (510) 642-2431

FAX: (510) 643-5470

E-mail inquiries: danrcs@ucdavis.edu

An electronic version of this publication is available on the ANR Communication Services Web site at http://anrcatalog.ucdavis.edu.

Publication 8157

This publication has been anonymously peer reviewed for technical accuracy by University of California scientists and other qualified professionals. This review process was managed by the ANR Associate Editor for Natural Resources.

(C)2006 by the Regents of the University of California

Division of Agriculture and Natural Resources.

All rights reserved.

The University of California prohibits discrimination or harassment of any person on the basis of race, color, national origin, religion, sex, gender identity, pregnancy (including childbirth, and medical conditions related to pregnancy or childbirth), physical or mental disability, medical condition (cancer-related or genetic characteristics), ancestry, marital status, age, sexual orientation, citizenship, or status as a covered veteran (covered veterans are special disabled veterans, recently separated veterans, Vietnam era veterans, or any other veterans who served on active duty during a war or in a campaign or expedition for which a campaign badge has been authorized) in any of its programs or activities.

University policy is intended to be consistent with the provisions of applicable State and Federal laws.

Inquiries regarding the University's nondiscrimination policies may be directed to the Affirmative Action/Staff Personnel Services Director, University of California, Agriculture and Natural Resources, 300 Lakeside Drive, 6 $6^{\text {th }}$ Floor, Oakland, CA 94612-3550, (510) 987-0096. For information about obtaining this publication, call (800) 994-8849. For downloading information, call (530) 297-4445.

pr-1/06-WJC/CR

ISBN 978-1-60107-326-6 